\title{
Disastrous Theology and Its Contribution in Encountering Covid-19 Pandemic
}

\author{
Abigail Annie Hutapea \\ Universitas Kristen Indonesia \\ Email: anniehutapea@yahoo.com
}

\begin{abstract}
In confronting a fast, vast and rapid growing and spreading of Covid-19 pandemic in all over Indonesia, it is needed to have a serious concern from every facilitator in this nation, including Christian Religious Education and The Churches of God. Especially, since this pandemic has brought a tremendous impact for social-economic life that has direct connection with welfare and harmony of both family and society life. Christian education and churches, where both of them are inseparable unison, in the end should be able in implementing Disastrous theology which is rooted from the Bible to encounter Covid-19 as the representation of the presence of Jesus in this world.
\end{abstract}

Keywords: Theology, disastrous, Christian Religious Education (PAK), Churches, Covid19 Pandemic.

\section{A. INTRODUCTION}

By substance and philosophy, implementing theology in Christianity is to think and to talk upon who, why and how God is according to the Bible. Whereas this is definitely inseparable from its terminology that consists of two syllables: Theos which means God and Logos which means logic/way of thinking. In other words theology is a thought and knowledge about God who is a Spirit, which is being discussed throughout human language and culture. Therefore theology should have the capability in thinking and talking about God within all aspects of human life in this world within its own civilization (Hutapea, 2021; Harrison, 1985:518). It means, theology should be able to be evidently elaborated about God's presence within every civilization of human existence in whole aspects of their life, where Christians education and churches in this world stand in the frontline. It is undeniable that the relationship between education in Christian religion strongly occurred with the existence of every single church in the face of this world. Especially, Christian education is always related with Chistian schools from

Kindergarten (TK) Elementary (SD), Junior High School (SMP), Senior High School (SMA), and also University level. Where their establishment most of the time is related with Christian foundations that lie under both individual and consortium churches. Therefore the existence of Christian education and the churches all round the world should implement Disastrous Theology in precise, especially in combating Covid-19.

Starting from all understanding as well as reality above, the Disastrous Theology that is fountained from the Bible is the basic foundation in all aspects of 
every Christians live, especially in Christian education and also in all churches. Moreover, theology should have the capacity to discuss everything, including the appearance of Covid-19 which is obviously under the knowledge of God, who is allknowing upon all things that happened recently in this world.

Therefore, it is crucial for Disastrous Theology to be elaborated in biblical perspective by Christian pedagogy and churches around the world, particularly in Indonesia, in order to give precise and quick answers in anticipating covid-19 which its spreading becomes wider and rapid and brings great impact upon socialeconomic life. This theology should also be able to be clearly and vividly implemented in Christian schooling and churches.

\section{B. LITERATURE REVIEW}

In the Bible numerous disasters in this world are mentioned, even the Bible also viewed far greater disasters beyond what we have encountered nowadays. Let's take a freshet for example (Genesis 7) which by fact is way beyond tsunami and even covid 19. But the interesting part is that in every disaster that we could find in the Bible is connected with God's deeds and plans behind it, which means no disaster in the Bible is disconnected with God (has no theological meaning). Disaster has a direct connection with God who creates The Earth and Universe in purpose for human beings to live in this world. As much as humans, who are created in the image and likeness of God, is exclusively the representation of God's figure to this world. In which through the image and likeness of God, humans are given the ability to represent God within every activity in his life (Ryrie, 1978:9).

To build a Biblical foundation about Disastrous Theology, it should be based on a thorough study of the Bible in understanding of the original language of the Biblical basis, because without any explanation of the basic understanding about the disaster itself at first, we will only become superficial in theology. And in the end we are unable in discerning Disastrous Theology itself. Moving from the basic understanding, we need to explain first what is disaster according to the Bible, next we explain the fundamental of Disastrous Theology by itself, and then we can relate the theology with Christian education and worldwide churches (especially in Indonesia), in particular when dealing with covid-19 as a recent global disaster.

The common Hebrew word that is always be used for disaster is "yed" which when translated into English would become calamity or disaster by using poetic language in expressing about "the judgement day" from GOD (Deuteronomy 32:35; Job 18:12; Obaja 1:13). That Disaster is a tremendously impactful event in destroying pillars of human living in this world. Within historical background (Deuteronomy and Obaja) as well as in the poetry book (Job) are not the outcome of mere imagination but because of real individual or community experience. Or it can be said disasters are trully happened in the historical life of humans in the world. Although the meaning of disaster is also written poetically in the book of poetry but it is not a product of imagination or liturgy in a service, it is a result of real 
experience of every believer of God that has been chosen by Him as His people or being atoned by Christ.

The idea of disaster in the Old Testament is really huge, and has direct connection with the concept of calamity in the New Testament which is synonymous with apoleia, alethros, and kathairesis. Where between the Old Testament and New Testament the meaning is related to the place awaiting for God's eternal condemnation, which in Greek is called HADES (Harrison, 1985:165). Therefore the meaning of disaster within the entire Bible (OT and NT) is always connected with God's miraculous providence upon His people and condemnation towards those who do not belong to Him. His providence does not mean preventing His people from disaster but purifying their faith to have more dependency in Him, The Almighty God. For those who disrespect Him, disaster acts as punishment. This catastrophe clearly shows God's authority upon human life and the universe, which is the core idea of Disastrous Theology.

The most interesting thing is when the Biblical original language (OT and NT) amazingly explains about Disastrous Theology, it actually has a direct relation with morality from the life of the people and also the community of believers in this world. Which means every disaster (whatever it is), including Covid-19 that happened in this world obviously has a straight connection with human morality or it is determined by respectful attitude towards God from human beings, as they are divinely created by God according to His Image and Likeness. Where the image of God has a true relationship of God's Attitude and Character that binds His People. Even it is directly projected through the meaning of human in Hebrew (Adham) which one of the meanings is innocent or has divine morality and character, and separated from sin (Gemeren, 1997:138; Zodhiates, 1994:2297). This is the reason why Disastrous Theology is strongly related with the education in Christianity. Moreover it is also related with the churches in which due to the background was emerged from the testimony of one of Christ's disciples (Peter), where the meaning of church (Eklesia) talks about calling and appointing from Christ Jesus as the head of the church towards every believer to enliven the Characters of Christ (original language Mat 16:13-20) (Zodhiates, 1992:901). This is why Disastrous theology is directly connected with Christian education and churches.

\section{METHOD}

Before reaching into further elaboration, the research methodology towards Disastrous Theology according to the Bible and her relation to Christian religious education and the churches in combating Covid-19 would be explained at first. Thw Methodology that is used is by doing literature study and gathering all information that related with theology, Christian education and Covid-19 as well. Next the researchers would practically describe it (in an applicative manner) in this article, therefore this would bring benefit in overcoming Covid-19. 


\section{RESULT AND DISCUSSION}

\section{Disastrous Theology in Christian Education}

Referring to the Bible as the base to emerge Disastrous Theology, this theology has to be able to be applied in all aspects of human life, especially Christian education. As it has been elaborated before, Disastrous Theology has a strong connection with the background of God-human relationship. Where in this relationship, human is dealing with Godly characters as the meaning of human itself emphasizing on holiness. And it is according to the statement of Christian religious education expert (Prof. Robert W. Pazmino), that said: "Christian religious education is "an intentional and systematic effort, supported by human and spiritual effort for knowledge, values, attitudes, skills and characters transmission, that is aligned and consistent with Christian faith, in order to emerge personal, group and even structural changes, renewal dan reformation because of the power of Holy Spirit, so that the participant's love according to God's will as it is written in the Bible, especially in Christ Jesus" (Baker, 1988:81).

The contention of Christian religious education is aligned with the purpose of the Christian pedagogy according to the Bible, which is teaching education according to the Biblical values where they should be applicable and bringing clear impact upon the attitude of each participant, even in dealing with the recent covid19 pandemic that is widely and rapidly spreading in Indonesia. Therefore the role of Christian education becomes significant in her contribution to every believer who encounters this pandemic.

Speaking about Disastrous Theology in Christian education actually can not be separated from participant's character development. Where this is emphasized by Paul in 2 Tim 3: 16-17 which is: Education in Christianity should give impact in the attitude and character transformations of every Christian who is trained in the truth. Therefore in facing covid-19 he/she is able to show the image of Christ or critical response that is aligned with the Bible (Henry, 1992:712). In which Christian education should be able producing divine character in facing any disaster in this world. Humans are created in the image and likeness of God (Gen.1:26). Even he is redeemed from the power of sin through the death of Christ on the cross (Romans, 3:23-24, 5:8). Therefore there shall be no reason for Christian religious education for not teaching the right attitude in embracing any disaster especially covid-19.

Disastrous Theology should be able to be implemented in the life of believers through Christian religious teaching on Christian schools in Indonesia, even when this globalization era has strong influence upon Christian education in encountering Covid-19: as stated before by Robert Rubianto (2009:8) that: "globalization era nowadays becomes a challenge that has transformed many aspects of life in society. The social phenomenon such as deviations that have been done by young generations that caused moral degradations". If not, there will be a character crisis upon each participant in facing Covid-19. 
Aside from that it is undeniable that Christian education is also determined by the teachers and lecturers who have integrity and are competent and expert on their field as one of the educational factors. Therefore the development of technology and science or changing of era, should not become the reason for Christian education for not teaching fundamental Disastrous Theology, especially in facing covid-19. Because Disastrous theology in Christian education should be able to play the optimal role in educating every Christian that is entrusted by God.

Christian religious education in schools is not only emphasized on teaching the dogma as what has been done until recently, such as giving Biblical knowledge about disaster, but also to educate, train and shape Christians in dealing with those disasters (especially towards Covid-19). In other words, this education should be capable of encouraging believers to avoid extreme reactions in comprehending and battling with Covid-19. For example understanding Christian faith that is against health protocol as government regulations, disbelieve attitude towards Covid-19, and even resist to be vaccinated because they believe that the vaccine manufacturers are part of Antichrist agenda. In reality lots of Christian attitudes have deviated from the Disastrous theology as the Bible had explained.

Therefore, it is crucial for these misleading attitudes to get serious treatments from Christian Education, who should involve every party as it is stated by Thomas Lickona (2012:xxvi), and Hasan Saragih (2008:27): "it is obvious that character education is not the responsibility of school alone, it is the responsibility of all parties who connects with values in young people, starting from family then widen to society of believers". In this case, all Christian educational practitioners should participate in the character educational movement starting from themselves, as an example for the students. Christian education is not only teaching, but also giving valuable contribution, which is shaping students' character. These two parties can not be dichotomized which is between the role of educators with their characters. In the other words, every Christian educator should be able to teach the principles and practicality of Christian faith, or even teachers from other subjects who are Christians, but the main focus would be character building.

There are a lot of factors in shaping students' characters, for instance: students' condition, availability of the facilities, good learning methods, and the role of Christian education practitioners themselves. Above all the factors, educators are the important components that need to have serious treatments". It means, every Christian religious educator has an important dominant role and influence in shaping e $\backslash$ the character of every participant. Therefore he/she is not only affected by situation and condition but how a teacher should make him/herself a role model to the students through his/her teaching and contribution can significantly impact upon shaping the character of the students in facing Covid-19.

Basically educators in Christian education are those who are being appointed by God in delivering teaching and education according to the favor that has been given to them. Educators in Christian pedagogy are one of the humane components 
in the teaching and learning process, who are also involved in attempting to emerge potential human resources on helping the government in succeeding the covid-19 contagious prevention program. Moreover educators should be able to do a humane approach which is giving help to every person in their surrounding. Even for every teacher is a figure who is in a very important position or has important roles in education (Law of the Republic of Indonesia Number 14 of 2005 concerning Teachers and Lecturers). According to the law: Teacher is a professional educator, with the main objectives are to teach, to educate, to guide, to direct, to train, to judge, and to evaluate students on children formal education on primary and secondary levels. Teacher has a unique and very complex role, beside as an educator, at the same time as a facilitator that gives guidance and leads the students to their goals and goodness. Even in the educational history, the teacher becomes a role model figure to the students, so a teacher should have strategies and ways in teaching.

In the New Testament, teaching can be seen as Jesus' ministry and due to Christian education can not be separated from Jesus Christ, who is a teacher that has been sent by God unto all of His creations. As teachers, the Jews refer Jesus as Rabbi or Great Teacher. Therefore the role of education in Christianity is determined on the quality of every education practitioner. Because as educators he/she has to have a personal quality standard that includes responsibility, independence and discipline. Moreover teachers in Christian education (PAK) as educators deal with equipping students with various needs in order to grow in Jesus Christ. Aside from that, as educators they also act as supervisors. Therefore their knowledge of Disastrous Theology is important in helping every student to be fully responsible, guidance and consideration towards Jesus Christ as a Great Teacher, especially in dealing with Covid-19 (Sardiman, 2007:125; Djamarah, 2005:1).

Every educator in Christian education is not only able to explain many notions about covid-19, but also should be able to help his/her students to comprehend the preventions of this pandemic. This is where the comprehension of Disastrous theology is needed by each educator, who also should be able to function as an instructor. Because in studying and understanding Disastrous Theology needs both intellectual and practical training and skills. Moreover each educator should be able to become a best friend as well as a respectable person towards his/her students. $\mathrm{He} /$ she should be able to have good communication skills towards every student of his/her, and at the same time have capability as facilitator in understanding the needs of the students in the understanding process in dealing with Covid-19.

Furthermore, every Christian religious teacher is required to do his/her part as an evangelist, as in reality he/she is also a missionary towards his/her students. This explains how important is the spreading of the gospel that can save every Christian from the fear of covid-19. Even Christian religious educator should be able to function as a priest and king or in other meaning has three dimensions which are: priest, prophet, and as king or leader". Therefore it can be said that Disastrous Theology in Christian religious education, especially in facing Covid-19 should have 
a scoop that covers: First; as far as Disastrous theology in Christian education in school can give a good impact to the faith growth upon every student nowadays. Second; as far as the responsibility of Christian schools especially each teacher in teaching Christian education to the students in responsibility and in quality. Third; as far as the role of Christian education teachers in emerging the goals of Christian education in the church. Last; as far as parents' responsibility in supporting Christian education in schools (Sidjabat, 2010:105).

Beside the four coverages above, there are four things as important in doing the task responsibility of Christian education which is: Christian education should be able to give practical explanation to the students about Disastrous theology through a proper teaching and learning process in the classroom. Next it should be able to be a source of enlightenment in giving living encouragement to each student in facing covid-19 through Disastrous Theology that is based on Biblical truth. This is aligned with Jesus' commandment: "Care for the flock that God has entrusted to you. Watch over it willingly, not grudgingly--not for what you will get out of it, but because you are eager to serve God (1 Peter 5:2)".

Therefore Christian religious education should be able to make every Christian become an example as a role model in overcoming covid-19. This is clearly stated by The Apostle Paul as mentor towards Timothy, his mentee: “Don't let anyone look down on you because you are young, but set an example for the believers in speech, in conduct, in love, in faith and in purity (1 Timothy 4:12)". This is how Christian education can bring everybody to experience a personal encounter with

Christ as a source of help in dealing with covid-19. Where this is based on Philosophical change in Christian Education which is to make us realize the importance of teaching that emphasized on clear vision and mission, as Christ has come to the world with a clear intention, to seek the lost, sinners to be saved.

As has been explained above, education in Christianity should be able to shape strong Christian characters. Where this is based on total submission upon Lord Jesus Christ that in the end will create character, attitude, the right response towards the truth of the Word of God. That assumption above explains about understanding Christian character as spiritual seeds (spiritual living value) that is rooted in the body and soul of believers and should be built consistently in faith upon Jesus Christ and in a personal communion with God within the power of the Holy Spirit. Therefore, the author's view that Disastrous Theology in Christian education should have capability in producing righteous characters, or showing who we really are as what Lord Jesus wanted in our life to proclaim the world (Mat 5:1416) in facing Covid-19.

The necessity of Disastrous theology in Christian education especially in dealing with Covid-19 is not separated from the main objective of Christian education itself which is to produce Christlike characters (comp. I John, 2:6). Where one of the benefits of this character itself is one is able to make decisions in life as a 
responsible human especially in facing this pandemic. Because Christian education that revolved in Christ, where through this kind of education established the right attitude of life is emphasized firmly by Christ Himself. This is the reason why Jesus invites people to come at Him and learn from Him, as He is humble and kind (Matthew, 11:28-30). Because the benefit of characters in human life can be explained in three crucial parts, which is as follows: for individual benefit, character really determines our life to Christ. Even S. H. Widyapranawa (2003:112), stated "if Christians want "to become like Christ" this is only possible when there is a radical change and a new life". It means, the character can build up an individual perfectly, as the way Christ lives.

Christian education that is based on the Bible can reflect Christ's character in each person's life. As it is written by Apostle Paul in Philippians, 3:17: "Brothers, join in imitating me, and pay attention to those who live according to the pattern we have set for you". Which means, the true Christian education is supposed to produce Christ Character as proof of our maturity in living this life. This is the importance of character in human life especially during the battle with covid-19. As the character shows the real you and the real me.

Beside that, the comprehension of Disastrous theology in Christian academies should also be beneficial to society. Because the benefit of character upon society is exactly as Jesus said in His Word "You are the salt and you are the light" (Matthew 5:13-16). Characters are supposed to be reflected in every real action in society in general, which means through characters that in line with Christian education our lives could become blessings not stumbling blocks towards society. Therefore Christian Education should be able to reflect Christ's Characters and Love on everyday life, and also can be perceived by the community around us. The Bible has clearly stated that you are the open scriptures of Christ that can be seen by others ( 2 Corinthians, 3:1-6).

Disastrous theology in Christian education should also be able to present the attitude of serving, which means, every Christian should function as minister of Christ. As the serving attitude is a strict command of Jesus Christ towards His followers (comp. John 12:26), where the benefit should be manifestly enjoyed by people surrounding us, as the Apostle Paul advised Timothy to be an example to all people (1 Timothy 4:11-16). This means that one should enliven the life that he/she preaches. Therefore Christian education should function as the primary medium to serve the society well, especially with the character that can be submitted to Christ. So that in every aspect of life he/she can reflect the attitude of a good and earnestly servant in total submission to Christ.

So in the end, the importance of character that produced by Christian education in Christian schools really determines the progress of human civilization in this world as it is mentioned by Thomas Lickona: "our characters determine how we act when nobody sees us, or as the old saying, "character is what you do when no one sees you". Ot means, character is the human values of life that are hidden 
within him/herself but able to be projected through good and right actions. Therefore Disastrous theology in Christian education should focus on how is the strategy of participants' character developments. As character and value development in someone's life is crucial in encountering various pandemic, especially covid-19.

Christian education should think of the principles and strategies of character building and development in dealing with covid-19, so that every Christian can reveal his/her true self that is being renewed by Christ. Especially towards those who were born in the midst of a family with bad attitudes and characters. As christian education should be able to transform the attitude of each participant that is built from kindergarten phase, education in school, basic attitude, religion, principal and motivation. The success of Christian education in building the character obviously is not a stand alone effort, but should involve many aspects both family, school and church, under the guidance of the Holy Spirit who reigns in human life. Therefore in facing covid-19 believers can become role models in this world, where it can be shown through the respect towards the government in dealing with covid-19, which is by supporting government's programs in finding the best solution for restoration of this nation, freedom from covid-19. Because fundamentally in the Bible every Christian is compulsory to honor the government by being in obedience in every policy especially in encountering covid -19 (Romans 13:1).

Christian education is supposed to have teaching strategies that centered on a person's character building, because this is the main objective beside emerging intellectuals. This is according to what Arozatulo Telaumbanua (2011) had said in his seminar that stated "there are three important points that need to be concerned in a person's character building process, which are "first; skills, there is responsibility, decision, beauty, and more. Second; attitudes within are: gratitude, personality, fear of the Lord, and Third; values, which are: honesty, learning, art". Which means through Christian education melalui every participant has character with integrity in facing covid-19, so he/she can be a good example to the surrounding community.

Character shaping can be done through education and teaching which are applicative, effective, creative, innovative, and dynamic. Education and teaching always become the important thing in student character shaping process, where through his/her knowledge about disasters, especially covid-19, he/she can follow learning process as mental and psychic activity that happened in active interaction with the environment that produces transformation in knowledge, experience, skill, values and attitudes (living characters). Therefore through Christian education that produces a strong mental, he/she can face covid-19 with the right and critical attitude without being overwhelmed by worries.

With this the teaching of Christian education and effective, creative, innovative and dynamic counselling can and is able to build up a student's character to become Christlike. The approach that is mentioned is the method and strategy 
that are used in the teaching and learning process in building character of teens, even adults through special approaching or Christian counseling. For instance first, using games like verbal games - to do word processing, like choosing synonyms upon words related with honesty, sincerity, kindness, and peace. Second; discussion concept - to do discussion about attitude concepts and temperament. In this activity, to exchange opinions, like listening and being listened, such as speaking courage and diligence. Third; giving praise - giving praise and support to students who can answer correctly, tell stories, and give good attitudes. Fourth; reward - give reward to children for their academic achievement or after to do something in proper and correct way. Fifth; second chances - giving second chances to students who failed in attitude, not just punishment. Sixth; memory - memorizing words of wisdom or quotations from famous people. Seventh; the opposite spectrum - have a discussion with students of both good and bad attitudes with their own consequences. Eight; observe to know good and bad things through conversations (Suprihatiningrum, 2014:15).

According to the opinion above, the author thinks that Christian education in her role to implement Disastrous theology should begin with the principals that emphasis on their parents and teachers' examplentary as their idol in building their characters. Moreover, it is important to have a good approach to interaction and communication between teachers and learners. Therefore through his explementary there will be a teaching learning interaction, clear communication between teacher and student in achieving the teaching objective, which is learning strategy of Disastrous theology's theories and her application upon overcoming covid-19.

To implement the approach in shaping the character of each participant needs competency and professionalism in order to give good results. Exemplary is the most primary in shaping and building participant character, which means every Christian educator should be able to set an example to their students. Therefore students are strongly motivated to act in maturity in actualizing their understanding of Disastrous theology so that they are able to encounter any catastrophe (especially on covid-19). It means, there will be no character development without exemplary Christian teachers. Next, Christian educators should be able to motivate students' parents in facing Covid-19, as their example in applying this theology has strong influence upon their children's characters and personality development.

Therefore Christian education should be able in producing a great, mature, wise, noble and stable personality also worthy to be set as an example and can be learnt by participants. With this kind of personality, exemplary can determine the learning process that builds up a student's character as instructional teaching objective. Life exemplary is a form of teaching that is delivered to students through both formal and nonformal education. Every Christian educator should have skill to teach Disastrous theology to every student, this also includes character building strategy. As skill speak about our ability to become role models, our spiritual life and our life exemplary to others. 
Furthermore Christian education should be able to provide Christian educators that function as parents that are able to do research, which have the best position in equipping students to grow mature and independent. And students should have the ability to ask constructive questions in the teaching process, being involved, and taking responsibility. Question that is not threatening is a very good way in helping students to think and recognize their own thoughts and be independent (Wright, 2009:52). The point is, character building strategy has principles and approaches that need to be improved by Christian education, in order for everyone, such as parents, teachers and pastors are able to be involved.

Therefore, character building can be done by using many strategies, principles and approaches, and one of them is skills. The Holy Spirit is the one who creates characters, and it has to be admitted, whatever strategies, principles and approaches that we use to build someone's characters couldn't work well without the collaboration and involvement of the Holy Spirit. The author also believes that human is unable to create ones own character, so no matter how beautifully Disastrous theology is elaborated in Christian education, and also no after how professional Christian educators might be, without the power of Holy Spirit it is impossible to create educated and trained Christians in implementing every theology, especially Disastrous theology.

Therefore the role of the Holy Spirit in Christian education is compulsory in building and renewing someone's character from bad into total restoration in Christ. Students character building is "a process and effort in shaping and repairing someone's personality from not good into go through Christian education teaching which includes firm and loving counseling, until students have Christlike characters within themselves because they are willing to go through shaping process for a transformation that is favoured by God".

In the end the author has concluded that Disastrous theology in Christian education has a tight connection with the building of Christian character as the answer of why and how every Christian supposed to understand, comprehend and act towards covid -19 that has become wider and taken more lives. Therefore the role of Christian education in implementing Disastrous theology is very important and becomes a necessity. Therefore they can do their job really well and are responsible in reaching the objective of a perfect learning. Even the Bible gives evidence that Jesus has given authority to apostles, prophets, teachers, prophets and evangelists to teach and to shape the characters of congregations (students) to be mature and perfect (Epphisians 4:11-16). Therefore every preceptors in Christian education need: 1) Maintaining holiness in life as God's partner in cultivating and guiding the students to be students with Christ's characters; 2) Realizing that he/she is a man of God, The duty of teaching is actually a calling from God that has to be done wholeheartedly. Christian religious teachers should prepare him/herself before teaching; 3) Christian education staff should become role models and able to mingle with students as part of their character building. 


\section{Disastrous Theology in Relation with Churches}

Basically church is the center in doing theology because church in the real meaning is every believer who testifies who Jesus really is in his/her tactical daily life. Therefore every Christian who wants to do theology should refer to his/her true testimony about who Jesus really is in his/her life, because upon this kind of testimony the church is built by Christ (Mat 16:13-20). So church in the real meaning does not refer to place and building but about the life of believers where Jesus reign within them, so even death has no power upon their life (Mat 16:13-20). Therefore Disastrous theology in her relation with churches on battling covid-19 is very important to be known by every Christian in order to face the rapid and worldwide contagious infection of Covid-19.

The Bible writes a couple of chatasthropies that happened in this world, such as the earthquakes in the era of Uzia -- King of Judah, and also the era of Jeroboam -King of Israel (Amos. 1:1; Zachariah .14:5). It seems that the earthquake was so tremendous and has a devastating impact upon the Israelites, as this event is recorded by two prophets: Amos dan Zacharia. However, there is no other source that recorded how this event had happened and the relation with the presence of God within this. Many disasters that are captured in the Bible contained specific meaning that God wanted to reveal towards humans in that period (Borrong, 2003:72; Scott, 1996:164).

As what the author has elaborated before about the meaning of Disastrous theology where it is strongly related with God's way in punishing His people, due to their deep degradation of morality, far away from the truth, so the truth meaning about disaster is God's Warning or Punishment towards humans. A devastating disaster that happened on human's life is recorded in the Bible when God punished His creations in the time of Noah with the Great Flood for their disobedience toward God for (Gen. 6:1-9:19). That Catastrophe becomes a warning as well as punishment upon His creation because their heart becomes undeniably evil (Gen. 6:5), which is appeared on their live attitude that has a tendency to do evil. This behavior makes God's Heart really sad and even the Bible has mentioned that God has "regretted" (repeated twice) because He had Created them on the face of the Earth (Gen. 6:6-7), which proved that humans evil deeds is already severe and couldn't be tolerated any longer. So the Lord said, "I will blot out man whom I have created from the face of the land, man and animals and creeping things and birds of the heavens, for I am sorry that I have made them" (Gen. 6:7). God punished His Creations with the Great Flood proceeding by heavy rains for forty days and forty nights (Gen, 7:12). This huge disaster acts as a radical judgement from God, because the food covered the entire Earth, which kills everything that lives (Gen. 7:19-23). This disaster brought death upon everything on the Earth, nothing could stand against it. The Flood flooded the Earth for one hundred and fifty days long (Gen. 7:24). The Disaster is not a coincidence (natural event), but really becomes God's judgement that has impacts towards human beings and all of His creations (Guthrie, 1998:91). 
The evil deeds of human beings not only impacted the humans themselves but also other creations of God. Then God has made a promise upon himself that He will never again "...cursed the Earth...and...will never destroy again..." (Gen, 8:21). There is no other disaster in the Bible that is more devastating and acts as God's Judgement upon Humans and other creations, although God still punishes humans through other catastrophes for their disobedience.

\section{Signs of God's Presence upon Human Beings}

There are a lot of things that God uses to show His Presence in the midst of men. One of the signs is the existence of disasters, such as earthquakes, written in the Bible. There are a lot of verses in the Bible that show earthquakes as a sign of God's presence in the midst of His People.

Not all earthquakes are the signs of the presence of God. In the OL it is mentioned several appearances of God upon His people, for example on the journey of the Israelites when they came out from Egypt to the Promised Land, God appeared to them at the Mount Sinai (Ex. 19:18). In that verse it is mentioned that the whole mountain was "tremendously trembling," these two words referring to the earthquake, where the mountain was extremely shaking that made the Israelite very petrified because God has come in the midst of them. God was ecstatically present at that time, it is proven by His conversation with Moses (Ex. 19:19-20).

The Israelites often experience God's presence in their life, one of them is when they have to fight with the Philistine. When Saul became a king, and his son Jonathan joined the battle against the Philistines, they gained victories because of God's presence in the midst of (I Sam. 14:15). The word "the Earth is trembling" clearly shows an earthquake, which happened because of God's presence to bring victory. Elijah also clearly perceived the presence of the Lord when he felt being the only one to be faithful in Him. God appeared to him preceded by an earthquake when Elijah was in Mount Horeb (1 Kings. 19:11-12). The word "earthquake" in these verses particularly explains the earthquake that happened when God appeared to him, and God truly appeared. As God asked Elijah, and he replied to Him, Elijah truly felt His presence. Isaiah wrote, "...Then one of the seraphim flew to me, having in his hand a burning coal that he had taken with tongs from the altar." (Isa. 6:6). Isaiah writing clearly shows how natural events can become the presence of God upon His people, and these natural events made people tremble in the presence of the Lord

In the New Testament, earthquakes also show the presence of God in front of His people. The event when Jesus died on the Cross and also at His Resurrection Day became the proof that God showed His Powers on those events (Mat. 27:51; 28:2). When Jesus died, an earthquake happened, and the proofs of the 143 clefted stones are recorded in Simpson's Journal, Volume I, Number 2, December 2014. This was not an ordinary natural event, but to show God's appearance to the people who were present at that time. This is approved by the testimony of the captain of the 
Roman soldiers who kept watch on Jesus, as they said, "Truly this was the Son of God!" (Mat. 27:54).The same thing happened when Jesus rose from the dead, the same great earthquake did happen. When Paul was jailed in Philippi, he encountered God in an amazing way, getting released miraculously by God, and this was preceded by an earthquake (Acts. 16:26). Paul is really sure this event is an evidence of the presence of God towards him and everyone who was there. This makes the warden believe in Lord Jesus. All of these events act as a strong evidence that disaster can become a sign of the presence of God to His people, and He wants to show His power towards them.

In both Old and New Testament in the Bible explain about disastrous events, ao that Disastrous theology has a strong Biblical foundation. Even it has strong ties between The Chosen People (OT) and the Churches (NT). Because the Church which is a Body of Christ or a life of believers that has been redeemed by Christ is a life testimony that presents God's power upon the world through his/her attitude that submit to the Truth of the Word of God. Disastrous theology in her relations with the churches reflects how God acts firmly in punishing the proud and arrogant humans for not respecting the Lord as their Creator and Savior. Therefore every believer (church) should be able to show the world on how Jesus acts as the leader of the church who has total dominion upon Christians' daily life.

\section{E. CONCLUSION}

From all of the elaboration above, it can be concluded that Biblical based Disastrous Theology is really important to be comprehended by every believer, especially in dealing with covid-19. Even more in her relation with Christian education as well as with the churches of God in her implementation in this world. Because Disastrous Theology according to the Bible in both Old and New Testament is connected directly with The Presence and Authority of God upon all disasters including covid-19, where every disaster is strongly connected with the punishment of God toward human being including Christians who are morally corrupt and who walked away from the truth.

As basic understanding about Disastrous Theology that has direct connection with the believers' attitudes and characters where they are emphasized as the main objectives of Christian education, so it is very clear that Christian education plays a very important role in educating and shaping Christian attitude answering the reason (background) why disasters appeared, especially the covid-19 pandemic. So that Christian education has a crucial role in preparing every Christian in facing covid-19 nowadays through repentance from moral degradation that had led them far away from the truth, and able to help the government in combating covid-19 through obedience in following and supporting every policy that has been issued by the government (as God's representative) to overcome covid-19.

Church as a spiritual institution in which believers should be able to show his/her true declaration upon Who Jesus is, within his/her daily life. Which means 
the declaration upon who Jesus is in his/her consciousness should be shown through his/her life in submission to the truth. This should bring a clear outcome for not having fear in facing Covid-19, such as equaling covid-19 with Hell (the place for eternal judgement), as Jesus Himself has given the authority upon every Christian that He has conquered the Death (Mat, 16:18).

In the end Disastrous Theology in her relation with the churches of God in this world should be pristinely seen through the right Faith and prayer. Where every member of the congregation should become the front-liner in giving the right example and become life exemplary in responding to Covid-19. The Church should also cooperate with the government in preventing Covid-19 through intercession prayers and respecting the government by obeying every protocol in battling Covid19.

\section{REFERENCES}

1. Baker. (1998). Foundational Issues in Christian Education. Michigan: Baker Book House.

2. Borrong, R. P. (2003). Etika Bumi Baru. Jakarta: BPK Gunung Mulia.

3. Gemeren, W. A. V. (1997). New International Dictionary of Old Testament Theology $\mathcal{E}$ Exegesis. Michigan: Zondervan Publishing House.

4. Guthrie, D. (1998). Tafsiran Alkitab Masa Kini 1, Kejadian-Ester. Jakarta: Yayasan Komunikasi Bina Kasih.

5. Harrison, E. F. (1985). Baker's Dictionary of Theology. Michigan: Baker Book House.

6. Henry, M. (1992). The NIV Matthew Henry Commentary in One Volume. Michigan: Zondervon Publishing House.

7. Lickona, T. (2012). Characters Education. Bandung: Kreasi Wacana.

8. Robianto, R. (2009). Characters Education Erasing Education. BAHANA, 217.

9. Ryrie, C. C. (1978). The Ryrie Study Bible. Chicago: Moody Press.

10. Sardiman. (2007). Teaching Motivations and Interactions. Jakarta: Raja Grafindo Persada.

11. Sidjabat, B. S. (2010). Teaching Professionally. Bandung: Kalam Hidup.

12. Stott, J. (1996). Isu-Isu Global Menantang Kepemimpinan Kristiani. Jakarta: Yayasan Komunikasi Bina Kasih.

13. Suprahatiningrum, J. (2014). Learning Strategies: Theories and Applications. Yogyakarta: Ar-Ruzz Media.

14. Telaumbanu, A. (2011). Education Teachers' Role. Seminar Materials in Yogyakarta, 28 June 2011.

15. Widyapranawa, S. H. (2003). Personal Characters Education. Yogyakarta: Taman Pustaka.

16. Wright, H. N. (2009). Menjadi Orang Yang Bijaksana. Yogyakarta: Andi Offset.

17. Zodhiates, S. (1992). The Complete Word Study New Testament. USA: AMG Publishers. 